\title{
Digital Human Resource Management: Prospects \& Challenges for Garments Industries in Bangladesh
}

\author{
Md. Hasan Mia* Fahim Faisal \\ Department of Management (MBA in HRM), University of Dhaka, Bangladesh
}

\begin{abstract}
Digital human resource management (HRM) popularly known as Electronic HRM has got immense popularity around the world including least developing countries like Bangladesh due to rapid automation, tech-based business era, presence and involvement larger community online, real-time response, gaining efficiency, and distance handling of HR in the workplace. Application of digital HR practices has faster the process, reduces cost, saves times, recruiting through social media, establish a brand and enhance the name and fame of the organization to the global community providing a platform of Human Resource Information System (HRIS). The study mainly reveals the current status, prospects, and challenges of using digital HRM in the garments industry in Bangladesh. To serve this purpose a focused group discussion has been conducted of most renowned eight garment factories along with digital HRM practices therein. Being the second position of readymade garments products exporting countries Bangladesh is certainly on the right track to capitalize on it with lots of prospects and challenges. Meanwhile, number one ranked China is moving on advancing on the automation.to keep track of this competition Bangladesh should not lag. Hence, the proper application of digital HR practices can be blessed to convert the mass into human resources.
\end{abstract}

Keywords: Digital HRM, garments industry, HRIS, social media, prospects, and challenges.

DOI: $10.7176 / \mathrm{EJBM} / 12-7-03$

Publication date:March $31^{\text {st }} 2020$

\section{Introduction}

Bangladesh is an agro-based country about $59 \%$ are directly involved with farmland and $80 \%$ reside in villages (Ministry of Finance, 2017). During recent decades she has experienced an industrial boom. At present, it is the second-largest readymade garment exporting countries in the world. Bangladesh can manage to so due to the cheap labor of illiterate and semi-educated mass especially from the villages (Bell and Sutton, 1998). Its industrialization paves the way to make the country technically more advanced and application of digital practices including management and HMR in evolving industries like readymade garments (Bell \& Sutton, 1998). At present different sectors has started to reap the results of digital practices in execution in different level of the organization (Aowrangazab, 2015). Besides, most of the buyers are from abroad, and hence, they prefer those organization which can fulfill the order and operates using digital technology, ensuring maximum benefits and safety for employees (BBS, 2018). The study reveals the prospects and challenges of digital HR practices in the different garment industry in Bangladesh.

\section{Literature Review \& Background}

i) Definition: Human resource management is the process of managing employees' skills, abilities, attitude, creativity, etc. for the attainment of strategic and long term goals and objectives of the organization (Rao, 2009). The digital human resource management (DHRM) often refers as e-HRM. According to Alexander (2008), digital human resource management is the application of the digital device, internet, and web-based systems to facilitate the interaction of employee, line managers and HR professionals in a single digital platform. Digital HRM is the transformation of processes and HR functions, and services with the use of mobile, cloud technologies, to ensure employee engagement, commitment, etc. also refer to the digitalization of HR. It is a proactive approach that includes, the HR planning, recruitment, learning, development, and retention of talents, performance appraisal based on web technology (Rouse, 2008). Furthermore, digital HRM can be defined as the process of formulating and implementing the policies, strategies, practices, and procurement via web-based technology in an organization (Ruël et al., 2004).

ii) Functions: Digital HRM reveals the immense scope of conducting the HR functions such as e-recruitment, employee support services (ESS), intranet and extranet services, management support services (MSS) and link to the HR department, and database in a digital manner (Brock bank, 1997). The DHRM has been so popular due to its utility of making it possible to bring all the functions of HR in a platform, improving HR service, reduction of cost and paper use, facilitates green HRM, improving formulation and implementation of HR strategy, and so on (Bell and Sutton, 1998).

ii) Benefits: Digital application of Human resource management has got immense application because it makes the HR functions and service easier, improve the process, systems, facilitates cloud-based system and streamline, real-time response, ensures transparency and accountability, enables of application of digital technology and so 
forth (Rouse, 2008). Other studies indicate the advantages of using digital HRM as improving employee efficiency, employee participation, ensures flexibility in the formulation and implementation of HR policy and practices within short, time and cost and saving, etc. (Bondarouk \& Ruël, 2009). It also facilitates the automation in HR practices, supports the HR executive to function based on the metrics and real-time data, creating virtual communities, remote working, etc.

iii) Elements: Digital HRM consists of three main elements such as operational, relational, and transformational. Operational HRM refers to the daily payroll, management of employee and administrative functions of the organization (Afroze, Hossan, Rahman, et, al. 2012). The training, online recruitment, performance appraisal, talent management, designing a reward system is considered as relational HRM (Bell and Sutton, 1998). Finally, talent management, strategic decision, organization restructuring to achieve $\mathrm{HR}$ goal is called the transformational HRM.

iv) Prospects and opportunities for Garments industry in Bangladesh: Digital HRM has got immense popularity around the world including least developing countries like Bangladesh due to rapid automation, techbased business era, presence and involvement larger community online, real-time response, gaining efficiency, and distance handling of HR in the workplace (Bell \& Sutton, 1998). The survey on the effectiveness of digital HRM reveals that being beneficial in time, cost and money by reducing the additional burden of workforces, it also facilitates the reputation and wide popularity of different social media. Most crucial is that the application ensures a healthy working environment and safety for the employees (Miah \& Hossain 2014).

\section{Objectives of the Study}

i) Primary objective: The primary objective of the study is to explore the prospects and challenges of digital HRM in the garments industries in Bangladesh.

ii) Specific objectives:

1) To identify the practices of Digital HRM in garments industries in Bangladesh.

2) To explore the prospects in the developing countries in garments industries.

3) To address the challenges with the appropriate suggestion for better practice of digital HRM.

\section{The methodology of the Paper}

This research is qualitative and descriptive. Hence, mainly qualitative data have been analyzed with the help of a table and graph.

i) Data collection: To serve the purpose, both primary and secondary data has been used. The secondary data is collected from various published sources such as journals, articles, books, published report, economic gazette, etc. Whereas the primary data has been collected by brainstorming and focused group discussion (FGD) with the executive, manager, and employees of the different top-ranked garments industries in Bangladesh.

ii) Sampling: For conducting a focused group discussion a sample of 50 employees of all levels from different well-renowned garments factories has been taken. Demographic profile of the sample is given below:

\section{Table-01: Profile of Respondents of FGD}

\begin{tabular}{|l|l|c|c|}
\hline Characteristics & Category & Number & Percentage \\
\hline Top-level & Male & 15 & $30 \%$ \\
& Female & 08 & $16 \%$ \\
\hline \multirow{2}{*}{ Mid-level } & Male & 12 & $24 \%$ \\
& Female & 08 & $16 \%$ \\
\hline \multirow{2}{*}{ Lower level and employee } & Male & 05 & $10 \%$ \\
\hline Total & Female & 12 & $24 \%$ \\
\hline
\end{tabular}

Source: Survey Data, 2019

\section{Discussion \& Result: Digital HRM}

Digital HRM has become a prominent function of Human resource management compared to traditional HRM. Digital HRM identifies the technology that enables the HR manager to formulate, implement HR policies, and processes for the effective delivery of human resource practices in the workplace to manage employee and resources most efficient and effective manner (Miah \& Hossain 2014). 


\section{Table-02: Justifications of Digital HRM}

Authors

Brown \& Martin, (2008)

Parry \& Tyson, (2007)

Bell, Yeung \& Lee (2006), Keegan \& Francis (2008)

Haines, \&

Petit, (1997).

\section{Justifications}

Digital Human resource management facilitates the automation of routine tasks such as e-learning, e-recruitment, e-selection, e-self assessment, e-performance management, etc. Hence, the garments industry can capitalize on the advancement of digital HRM practices for improving overall performance and talent management.

Digital HRM practices relieve the conventional administrative pressure by converting manual tasks into digital form. Hence, this reduces the amount of paperwork drastically. Furthermore, the practice also empowers the managers for well HR practices and facilitates development.

Digital HRM transforms the managers and HR professionals from conventional paper handlers to a well-linked strategic partner. It increases the facilities of collaboration and learning such as training, facilitating learning, designing payroll and sharing decision, employee feedback, grievance management also get a faster pace due to the use of digital HRM practices

Digital HRM helps successful implementation HRIS, a survey of 152 users of HRIS reveals that individual, organizational and system conditions needed the support of digitalization which can be ensured by the use and application of digital HRM.

Ball, (2001), Thaler-Carter, Another quantitative study of 115 organizations has found that application and practice digital HRM and HRIS firstly depends on the size of the organization. Secondly on the modules, in house logistics, use of flexible software, etc.

Lepak, \& Snell, (1998), Ngai, \& Wat (2006).

The digital HRM refers to many things in labor-intensive organizations such as the garments industry. For instance, virtual HRM, web-based HRM, Human Resource Information Systems (HRIS), etc.

Patra, Khatik \&

Kodwani, (2002)

Different well-known organizations across the globe including garments organizations are using social media such as Twitter, LinkedIn, Facebook, WhatsApp, Skype, teleconferencing for selecting and promoting their organization and attract talents in the recruitment procedure. Moreover, employee and organization related information is provided with the help of Facebook and online group which helps the manager an edge to manage people more efficiently.

\subsection{Digital HRM practice of garments industry in Bangladesh}

For the flourishing garments industry in Bangladesh, Digital HRM can be considered as a tool for maximizing the capacity of HR practices gaining competitive advantages with minimum time and effort. This practice enables the organization to create strategic partners including the employers and employees ensuring their development and scope for maximum contribution for the organization. The focus group discussion the following information has been collected regarding the digital human resource management in perspective garment factories below:

i) Ha-Meem Group: It is one of the conglomerates in textile and garment owning 26 textile and garments factories with about 50000 workers and annual revenue US \$500 (Saha, 2012). This organization is one of the best organizations practicing HRM functions based on the digital use of HR practices. They are very cautious about the working environment (Miah \& Hossain 2014). So, they put their best effort to reduce the impact on the environment and pollution. They have introduced online database management systems, attendance through digital ID card, surveillance and monitoring employee by close circuit camera, digital schedule of work, online payroll management, salary, and wage payment with the use of online and mobile banking such as Bikash, Rocket by DBBL, sure cash, etc. To ensure a worker-friendly environment Ha-Meem group has installed carbon emission measuring meters. Moreover, to minimize and reduce dust and fume appropriate emission and ventilation system has been realized.

ii) Beximco Fashion Ltd: Beximco Fashion Ltd. is a sister concern of the Beximco Group. To ensure safety measurement this organization uses a digital alarm system in case of fire break and sudden earthquake. Along with the digital payroll system, it uses an individual tracking system for the employee called the digital identity card. By this tracking system employee attendance is recorded automatically, including the time of entrance and departure. They also introduce the data black box which mainly a software literary not destructive in case of fire. This stores the records of the employee in case of sudden accident and fire break. 
An online suggestion box is another remarkable step for enhancing the name and fame of this organization.

ii) Fakir Apparel Ltd: Fakir Apparel uses HR and payroll software supported by Logic Software Ltd. maintaining manpower budget, employee transfer and promotion, online-based training, attendance, leave and payment management; storing basic information of employees, and introducing web-based appraisal system. It initiates interactive training and learning sessions through uploaded videos of how the task is completed by employees.

iv) DBL Group: DBL generates information about candidates and attracts job seekers through software called "Taleo". HR department asks the candidates to attend the primary interview through SMS and to present the final interview through Email. It maintains an online-based Candidates' Assessment Sheet for selected candidates. It keeps the web-based records of employees, it has also introduced the E-learning hub for the employees and initiated the training program through Microsoft Excel and Microsoft PowerPoint (Miah \& Hossain 2014).

v) Epyllion Group: This is one of the most renowned garments factories in Bangladesh based on the direct export of readymade apparel. They perform most of the Human resource activities through online, such as the advertisement for the employee, online form fill up, reception of employee information and storage, all class of employees have easy access to their data, and there are regular updates and modification of data with the passes of time. The online application is a quick and reliable means for the employee from the remote part of the country to apply. Furthermore, in this era of social media, they can easily reach to all class of people using smartphones. They pay employees via online and mobile banking namely Bikash, Rocket by Dutch Bangla Bank Limited, ATM card, etc. here all of the employee has a particular tracking number and at the end of the month, their salary is deposited in their perspective bank accounts.

vi) N. R Group: The main products of the NR group are the knitwear, sweater, and quality T-shirts. This is a digitized organization because most of the activities and processes are conducted digitally. Automation has a remarkable mark in HRM also. Data management software, online payroll, apply of the digital scorecard for employee evaluation, automated employee record keeping, digital alarm and safety measurement on vulnerable time, etc. They mainly focus on online recruiting and recruiting through social media.

vii) Kaniz Fashions Ltd: Kaniz Fashions Ltd. focuses on E- technology in HRM practices. Kaniz Fashion uses Fast react software to assist retailers, improve business execution, and enhance the proficiency of operations and pliability of the supply chain. This group also uses Kormee Software for maintaining worker's information including recruitment, payroll, etc. Kormee Software helps to keep the records of attendance, leave and payroll of employees. Kormee Software is an HRIS software. Kaniz Fashions Ltd. has introduced a digital chip for employees which reduces the hassles of taking individual attendance manually.

viii) Viyellatex Group: Viyellatex Group is one of the renowned and largest garments factories and exporters around the world and has around 13000 employees and earned \$ 200 million annual gross revenue ('Viyellatex Group' website). It attracts and recruits employees and interns through Websites (BD jobs etc.).Pools of candidates are also attracted through Social Networking sites, SAP data entry, and BD jobs.com and so on. HR department checks and prove actual documents, medical details, NID cards of candidates through online. It stores the $\mathrm{CV}$ of the candidates in a database for future use. Email is the crucial mode of communication among inter-departments and outsiders.

\subsection{The use of digital HRM reveals the following prospects for the garments industry in Bangladesh.}

1. Facilitates efficient HR practices and services with minimum effort and within the shortest period such as recruitment, selection, placement, learning, and development, etc. Thus using digital HRM is a must in the era of digitalization in Bangladesh, which helps to improve the overall performance of garments and textile factories.

2. Improve the quality of services, helps to achieve competitive advantages, and get things done with efficiency and minimum time, cost and effort.

3. The use increases the HR efficiency and effectiveness providing a birds-eye view of the whole organization and proper management of resources and appropriate decision.

4. Prompt routine tasks such as record keeping, employee information, and data, employee payroll, keeping attendance, monitoring employee performance, succession management with the help of digital technology. 


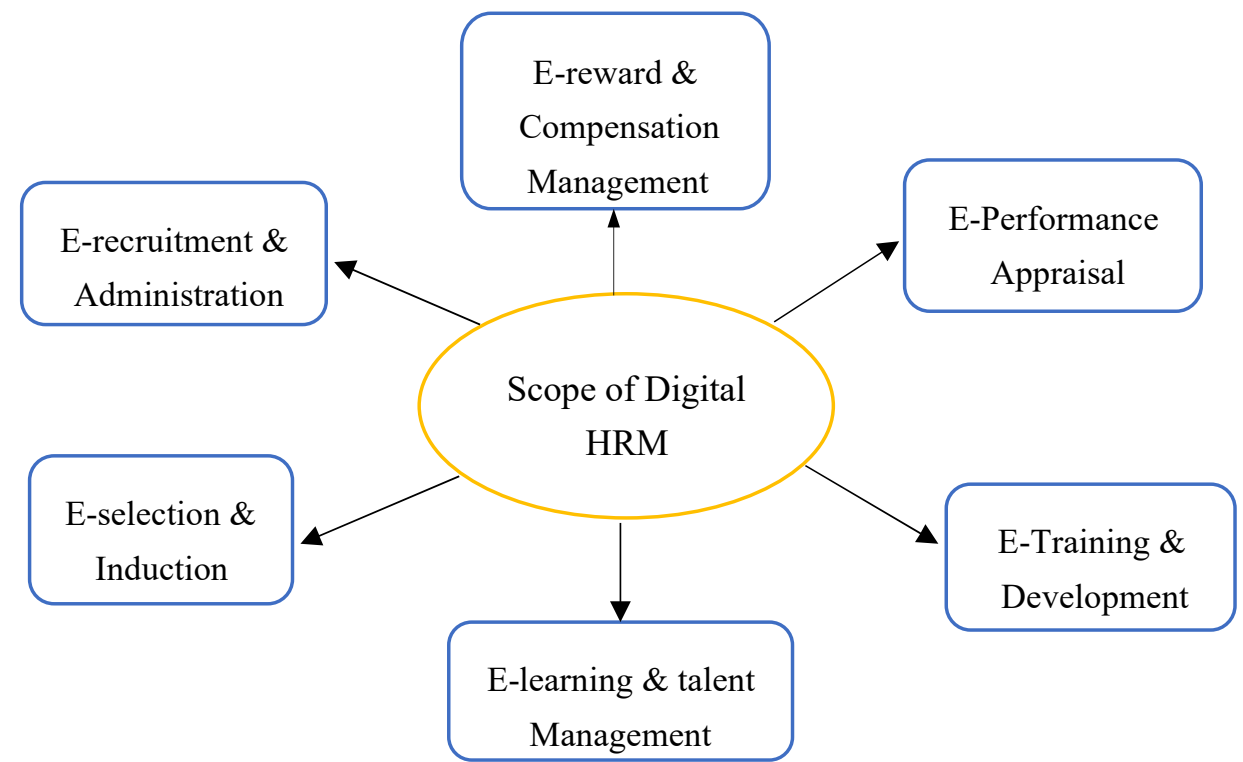

Figure-01: Scope of Digital HRM, Source: Author, 2019

5. Improve accuracy and reducing human error and bias by the use of an HR scorecard, digital dashboard, and strategic map.

6. Standardization and automation in all level of management

7. Huge data and information about the employee and other resources can be stored with the help of digital database management systems. This enables the organization to keep data and information more secure and confidential. Such as Oracle RDBMS, IBM DB2, Microsoft SQL server, ADABAS, MySQL, etc.

8. Electronically stored data can be efficiently stored and retrieved easily. There is no chance to misplace the information and it takes virtually no places for storage.

9. Due to the introduction of digital human resource management, employees are not merely confined to geographical location nowadays. The employee can involve outsourcing at a free and easy time. This generates extra income. On the other hand organization also can meet up the employee shortage via online outsourcing by the employee both in-home and abroad.

10. Distance management of employee's wit fair and justice by web-based technology.

11. Order from foreign delegates is received and procured digitally, moreover the products display, price list, bargaining and settling price all these things are done with the help of digital and web-based technology.

12. Most of the banking activities are performed online. Hence, the garment industry conducts their regular transactions with banks digitally.

13. Digital HRM reduces the utility costs of administration, improve the image of the organization, attract more qualified and talented employees, and improve productivity and sustainability with maximum use of resources.

14. Improves employee morale, reduce turnover and absenteeism, reduces the grievances, increasing organizational citizenship behavior (OCB), and facilitates easy identification of problems, quick decision, and strategy formulation.

15. About $93 \%$ of employees have a mobile phone. It makes the implementation of digital HRM easier. Moreover recruiting from social media can be a cost less recruitment system for the organization such as Twitter, Viber, WhatsApp, Facebook, LinkedIn, etc.

\subsection{The use of digital HRM poses the following challenges for the garments industry in Bangladesh}

Challenges of digital HRM for the garments industry in Bangladesh: the study reveals the following challenges after visiting and focused group discussion of the three most famous and well-known garments organization in Bangladesh.

1. Being a developing country, the garment industry is in a flourishing position. Hence, introducing digital practices especially in HR practice and policy formulation requires lots of expertise, support and initial funding at this initial level. But most garments organization are quite small in terms of capital investment and skilled manpower. So, introducing and practicing digital HRM poses lots of challenges in this regard.

2. Digitally enabling employee management and payroll may hinder the co-operation, collaboration, team efforts, and employee-employer relationship in the long run. This creates automation and treats people 
as a clog of the machine which drastically hampers and destroys the co-operative and sharing organizational culture.

3. Digital employee data management creates chances to alter, fabricate, destroy and mismanaged by the corrupted officials.

4. The attack of a virus can destroy the whole system within a glance. Eventually, the software may malfunction and act other than the expectation due to cybercrime, such as hacking, cyber vandalism, farming, fishing, redirecting, spam, etc. this poses great challenges for practicing digital HRM.

5. Traditional management view often prefers paperwork to online-based management. Here, the skill obsolesces can resist the change and transformation of e-HRM. Therefore, this another challenge for digital HRM in the garments industry in Bangladesh.

6. For improving the skills, abilities and knowledge management, the garments industry needs to invest a huge amount of money. But it is quite a luxury for the small and medium garments to make employees capable of adequate training and development initiatives. Hence, getting capable personnel to facilitate digital HRM to arrange and invest funds is another challenge for the garments industry in Bangladesh.

7. Illiteracy is another hindrance to the application and practice of digital HRM in garment industry most of the employees are illiterate and don't have prior knowledge about handling digital tool. So, without proper development and education about the use of digital technology, this practice will not be able to utilize the opportunity fully.

\subsection{Proposed Model for effective digital HRM in the garments industry}

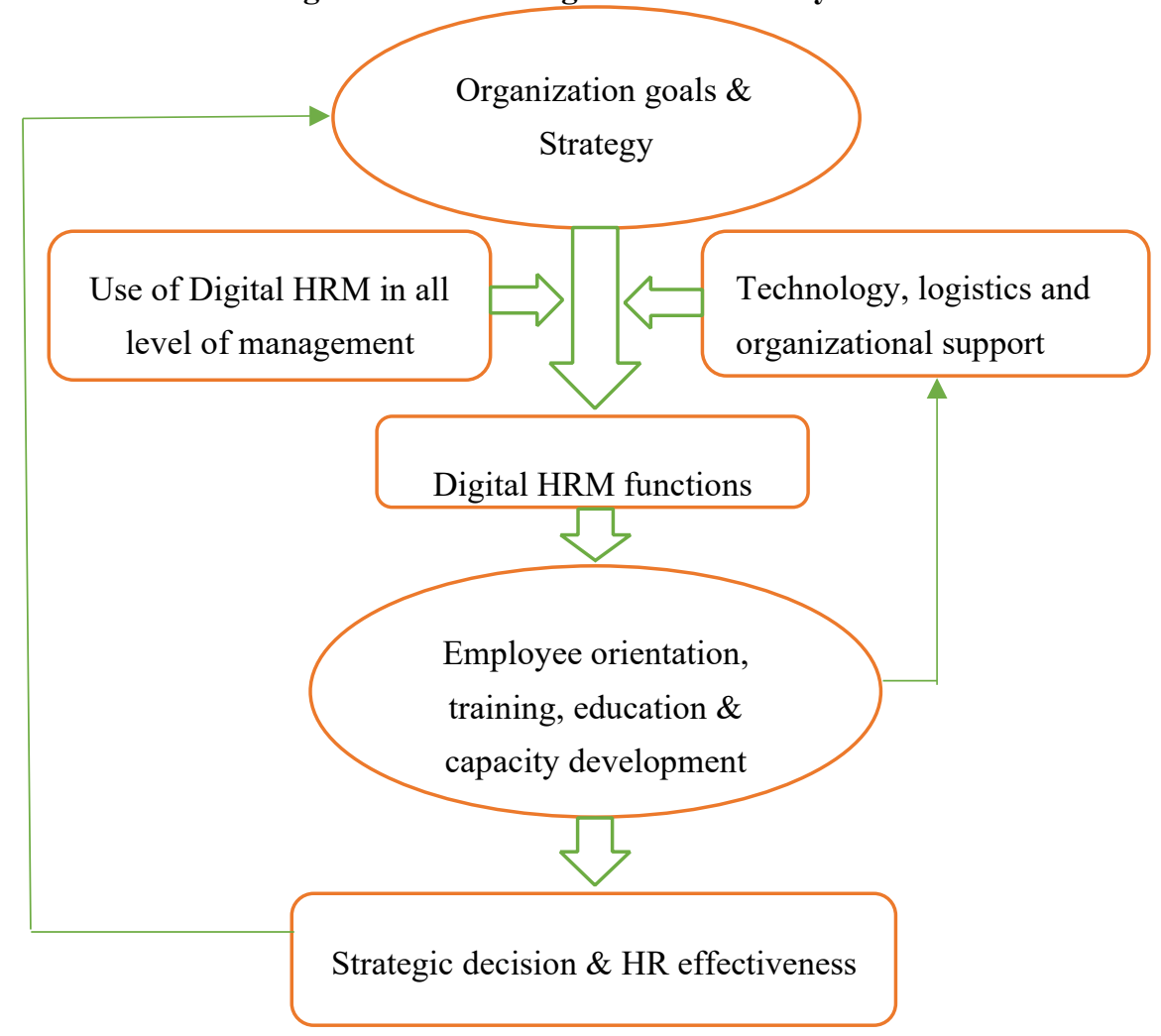

Figure-02: Proposed model for effective digital HRM, Source: Author, 2019

\subsection{Suggestions to ensure digital HRM practice in the garments industry in Bangladesh}

1. Increase technology know-how, expertise for the organization to ensure all things are done and initiated digitally. All levels of employees should be involved ahead of gender disparity.

2. Usability of technology and resource. Proper expert personnel needs to be appointed to monitor and manage the system with HR audit and accountability to trace the fraudulent activity and cyber vandalism.

3. Facilitates training and development opportunities for the employees. Prioritize personnel technically advanced and keep to implement technology in the workplace. Hence, training in using advanced technology should be introduced.

4. Understanding and raising awareness of the advantages and positive impacts of digital HRM on the 
environment. The organization can pave the way for green HRM by the implementation of digital HRM in garments industries.

5. The online recruitment and application process should include more information and proper instruction regarding the organization, history, and purposes. Advanced CV bank can be established by using the merits of social sites such as LinkedIn \& Facebook.

6. For better management and decision making feedback of customers and stakeholders is crucial. Using social sites voting pool, complain and suggestion boxes can be established to get regular feedback.

7. To ensure the employee loyalty garments industry need to be transparent to the employee which can be possible by electronic HRM. Such as Employees should have access to organization payroll, salary, bonus, incentives, skill inventory, promotional criteria, succession planning so that they can be informed who are performing more and get promoted for which reason. This also reduces the grievances and organizational conflicts.

\subsection{Conclusion}

To keep pace with the digitalization, all the garments industries including small and larger seem to be eager to practice the HR function by the help of digital means. Not only this sector but also all the other sectors including banking, finance, government services, judiciary, etc. the digital application to manage human resources in the workplace is increasing day by day. Hence, there is a boom of digital HR practices in garments industries in the last decades due to the online reliability and worldwide acceptability. Moreover, digital HRM makes all the required information transparent to the employees which drastically reduces the grievance and inter conflicts.

\section{References}

Afroze, R, Hossan, C.G., Sarker, M., and Rahman, A., (2012). An Assessment of Managerial Skills in the Labour Intensive Industry: A Case Study of a Garments Manufacturing Firm. Journal of Accounting, Business \& Management, 19(2).

Aowrangazab, A (2015), 'Industrialization process in Bangladesh: An evaluation of the role of the state, policy measures, strategies, problems, and prospects', Unpublished doctoral dissertation, University of Chittagong, Bangladesh.

Ball, K.S. (2001). The use of human resource information systems: a survey, Personnel Review, 30, (6), 677 693.

Bell, B.S., Lee, S.-W., and Yeung, S.K. (2006), 'The Impact of e-HRM on Professional Competence in HRM: Implications for the Development of HR Professionals,' Human Resource Management, 45, 295- 308.

Bell, R. S., and S. W Sutton, (1998), Building your online recruiting presence, Human resource professional, Vol. (11), pp. 10-14.

Bondarouk, T. V., \& Ruël, H. J. M. (2009). Electronic human resource management: Challenges in the digital era. International Journal of Human Resource Management, 20(3), 505514.

Brockbank, W. (1997), "HR's future on the way to a presence", Human Resource Management, Vol. 36 No. 1 , pp. $65-70$.

Brown, D. (2002), 'e-HR - Victim of Unrealistic Expectations,' Canadian HR Reporter, 15, 1.

GOB, Bangladesh Bureau of Statistics, BBS, (2018), Statistical pocketbook of Bangladesh 2018, Dhaka

GOB, Ministry of Finance (2017), Bangladesh economic review 2017, Dhaka

Haines, V., \& Petit, A. (1997). Conditions for successful human resource information systems, Human Resource Management, 36, (2), $261-275$.

Keegan, A., and Francis, H. (2008), 'HRM, Technology and Strategic Roles: Considering the Social Implications,', pp. 421-447.

Lepak, D. P. \& Snell, S.A. (1998). Virtual HR: Strategic human resource management in the 21 st century. Human Resource Management Review, 8: 215-234.

Martin, G., Reddington, M., and Alexander, H. (2008), Technology, Outsourcing and Transforming HR, Amsterdam: Elsevier.

Miah, M.K. and Hossain, M.S., (2014). A comparative study of HRM practices between foreign and local garment companies in Bangladesh. South Asian Journal of Human Resources Management, 1(1), pp.67-89.

Ngai, E.W.T. \& Wat F.K.T. (2006). Human resource information systems: a review and empirical analysis. Personnel Review, 35: 297-314.

Parry, E., Tyson, S., Selbie, D., and Leighton, R. (2007), HR and Technology: Impact and advantages, London: Charted Institute of Personnel and Development.

Patra, R. K., Khatik, S. K., and Kodwani, A. D. (2002). Human Resources Professionals at the Crossroads. International Journal of Human Resources Development and Management, Vol. 2 No. 3/4).

Rao, P.S., (2009). Personnel and human resource management (pp. 236-345). Himalaya Publishing House.

Rouse, M. (2008). What is digital HR? - Definition from WhatIs.com. [online] Search HR Software. Available at: 
https://searchhrsoftware.techtarget.com/definition/digital-HR [Accessed 10 Oct. 2019].

Ruël, H.J.M., Bondarouk, T.V. and Looise, J.C. (2004), E-HRM: Innovation or Irritation? An Exploration of Web-Based Human Resource Management in Large Companies, Purdue University Press/Lemma Publishers, Utrecht.

Saha, G.C. (2012), The Influence of Strategies on Human Resource Information Systems: An Analytical Study on Ha- Meem Group, Bangladesh. Bangladesh Research Foundation Journal, p.73.

Thaler-Carter, R.E. (1998). The HRIS in small companies: tips for weighting the options, HR Magazine, 43, (8), $30-35$.

\begin{abstract}
About the Author
*Md. Hasan Mia. Md. Hasan Mia is currently pursuing his Masters of Business Administration (MBA) degree in Human Resource Management (HRM) at the Department of Management, University of Dhaka, Bangladesh. He was born in 1996 in Munshiganj, Dhaka, Bangladesh. He was a meritorious student from childhood and achieved golden GPA-5 in SSC and GPA-5 in HSC. He has also secured the third position in Bachelor of Business Administration (BBA) at the Department of Management, University of Dhaka. He has an excellent academic background and a keen interest in human resources, mathematics, TQM, recent business issues, entrepreneurship, and information technology.
\end{abstract}

Fahim Faisal: Fahim Faisal is undertaking his Masters of Business Administration (MBA) degree in Human Resource Management (HRM) at the Department of Management, University of Dhaka, Bangladesh. He was born in 1997 at Dhaka, Bangladesh. He secured GPA-5 both in SSC and HSC. He also passed a Bachelor of Business Administration (BBA) from the Department of Management, University of Dhaka. He has a profound interest in human resources, total quality management, management science, IT, economics and entrepreneurship. 